\title{
Review
}

\section{Global justice, natural resources, and climate change}

Megan Blomfield,

Oxford, Oxford University Press, 2019, 253pp.,

ISBN: 978-0-19-879173-7

Contemporary Political Theory (2023) 22, S14-S17. https://doi.org/10.1057/s41296021-00529-2; published online 4 October 2021

If Naomi Klein is correct that an anthropogenic global warming trend 'changes everything', then it must also change political theory - in its methodology, presuppositions, and conclusions. By and large, however, this change has not taken place. Just as governments, corporations, and consumers continue with business as usual, as if an ecological catastrophe were not looming on the horizon, political theory carries on its conversations as if climate change were only one issue among many. Political theorists do talk about climate change, of course, but typically as a mold into which applications of various theories are poured. Such accounts tend to operate in isolation from the minutiae of climate change as it is actually unfolding, treating it instead as a simple tragedy of the commons or as a springboard to talk about other, supposedly more interesting things. The theory changes how we think about climate destabilization, rather than climate destabilization changing how we theorize. Meanwhile, a multitude of texts enumerate the various facets of the catastrophe in real time, but understandably leave to one side the classic questions of political theory (like 'what is justice?').

Blomfield's Global Justice, Natural Resources, and Climate Change represents an attempt to bridge the chasm between an empirically-informed and detailoriented reflection on climate change and a philosophically sophisticated reflection on the nature of justice. In the book's most compelling moments, she juxtaposes prevailing theoretical positions with the assessments of the Intergovernmental Panel on Climate Change (IPCC), often finding the former wanting. To those who regard the atmosphere as a global commons, and justify the view that 'emission quotas should be distributed to all human beings globally on an equal per capita basis' (p. 27), Blomfield points out that the atmosphere is only one climate sink among many; vegetation and soil also absorb greenhouse gases, and these do fall within territorial boundaries (p. 34). An equal right to the atmosphere is not equivalent to an equal right to the global climate sink. If the 'equal per capita emissions' view is defensible, then, it requires further justification. This is but one

(c) 2021 The Author(s), under exclusive licence to Springer Nature Limited. 1470-8914 Contemporary Political Theory Vol. 22, S1, S14-S17

www.palgrave.com/journals 
example of Blomfield allowing the specific contours of the climate situation to guide the analysis, not allowing concepts to forget their relationship to objects.

Nevertheless, the book remains firmly rooted in philosophical concerns. While I cannot catalogue the distinctions that Blomfield navigates or the diverse positions she adopts in the course of building her argument, suffice it here to take note of a few central conclusions. Approaching the issue of climate justice responsibly, she argues, requires a defensible theory of natural resource justice. Because natural resources are essential for human wellbeing, but exist independently of human beings, everyone has an 'equal original claim' to them (p. 52). This is best understood as implying common ownership, the view that each individual has an original moral claim to the use of resources, but lacks any such claim to the exclusive use of resources. An exclusive claim to resource use can be justified subsequently through an 'original position' social contract device. 'Contractualist common ownership' would then result in two fundamental principles: the basic needs principle, according to which every human being is entitled to the 'natural resources that are necessary for satisfying their basic needs' (p. 101), and the principle of collective self-determination, according to which every political community is entitled to "natural resources that are necessary for engaging in the legitimate exercise of collective self-determination' (p. 119). That the first principle has 'lexical priority' (p. 126) to the second is important: self-determination suggests a degree of territorial jurisdiction, but this can be abnegated if it interferes with the basic needs of others (p. 126); territorial jurisdiction is always presumed though usually limited by other concerns (pp. 128-141).

At this point, the book deftly but palpably changes lanes; while the empirical findings of the IPCC had often supervised the conceptual sorting of the first twothirds of the text, the last section tightly tethers the abstract question of emissions debt to the concrete history of colonialism and neocolonialism. Instead of John Rawls and Charles Beitz, we see citations from Frantz Fanon and Aimée Césaire (pp. 199, 203). The reason that high-emission countries owe a debt to low-emission countries, Blomfield argues in a welcome corrective, is not simply that the former have emitted while the latter have not; for most of its history, fossil fuel consumption as such was not morally questionable. Rather, a 'climate debt' is incurred because differential levels of development render some parts of the world more vulnerable to climate destabilization and less able to either adapt or mitigate. This difference in development, in turn, belongs to the history of colonialism and the ongoing conditions of neocolonialism (p. 203). Because the work is concerned with natural resource justice, Blomfield focuses on 'colonial resource exploitation' (p. 193). In what might be the book's most necessary section, she connects the inequalities of the current climate situation to the material legacies of colonialism, rather than limiting the discussion to domination in the abstract (pp. 203-206). The last chapter keeps close at hand a truth so often forgotten in reflections on global

(C) 2021 The Author(s), under exclusive licence to Springer Nature Limited. 1470-8914 Contemporary S15 Political Theory Vol. 22, S1, S14-S17 
inequality: that 'underdevelopment' is something done to formerly colonized places and not a natural condition of their being (p. 210).

As I have already indicated, this juxtaposition of pure theory, on the one hand, and historical, geopolitical, and scientific texture, on the other, is one of the book's great strengths. It is also, however, a source of tension. In her discussion of collective self-determination, for example, Blomfield appeals to Margaret Moore's 'non-statist' definition of a 'people' as those sharing 'political identity, political capacity, and political history' (p. 116). In our mundane political reality, this definition is difficult to apply. To which 'people' does a Cuban exile in Miami belong - Cubans? Americans? Cuban-Americans? Is she also a member of the African diaspora? Is she pro or anticommunist, and do these constitute different 'peoples', each with a right to self-determination? Given the overlapping and often contradictory nature of Moorean 'people', it is difficult to see how this understanding could help delineate a notion of collective self-determination, especially in disputes over natural resources. Connected back to climate change, the issue becomes murkier. Do Norway, Saudi Arabia, or Venezuela have the right to keep pumping oil? Does the state of Oklahoma have the right to reject federal limits on fossil fuel consumption? Presumably, these are cases where the lexical priority of the basic needs principle, or the necessity of opposing domination (p. 170), would intervene and override the principle of collective self-determination. But given how quickly and how sharply greenhouse gas emissions must be reduced - which Blomfield underestimates, now out of step with current IPCC projections (p. 163) - it is difficult to imagine the latter principle doing more good than harm in the real world. The exceptions, in other words, would appear to be so numerous that the rule could no longer be called a rule.

This points to a broader methodological ambivalence in the book. As mentioned above, Blomfield often lets the world do the talking when it comes to climate change - if a theoretical notion is incongruous with an empirical state of affairs, the former must be revised. With regard to the self-determination principle, however, this precept is almost altogether dropped. There is no mention of popular climate skepticism, of the well-funded denial industry (and its motivations), or of the growth-dependent logic of capitalist production. The ostensible explanation for this is a circumscribed scope: Blomfield emphasizes several times that her analysis is only 'partially integrated' (concerning natural resource justice, not global justice writ large) (pp. 22, 147). But if an adequate understanding of the scientific realities of climate change is necessary for a coherent account of natural resource justice as the book so successfully demonstrates - why should political-economic factors directly pertinent to climate mitigation and adaptation be left to one side? Would these factors not also be essential for such a theory? While the book is often remarkably successful at balancing its high order abstractions with empirical specificities, there are moments where the latter falls off and the former takes over, 
giving in to the common habit of treating climate change as a case study instead of, as in the text's finer moments, building a theory from the raw material.

This raises the more fundamental question of whether a Rawlsian 'original position' device is the appropriate tool for thinking about a warming world. When Blomfield's arguments are compelling (which is frequently), it is when she is closer to history and science and further away from the philosophical methodology that is meant to the govern the argument. The text comes to life when it treats the 'climate' in 'climate justice' as a noun rather than an adjective, when the specific empirical details of anthropogenic climate change - its causes, consequences, social mediations - regulate the normative account, as opposed to simply tinting an existing framework green. Perhaps it is the case, then, that the climate catastrophe demands that philosophy become less philosophical. Alternatively, we might say that a rigorous engagement with historical and material realities is a condition of good philosophy and not merely a supplement to it - or, as Karl Marx said so long ago, that the task of philosophy is to abolish itself as merely philosophy.

Publisher's Note Springer Nature remains neutral with regard to jurisdictional claims in published maps and institutional affiliations.

Larry Alan Busk Florida Gulf Coast University, Fort Myers, FL 33965, USA lbusk@fgcu.edu 